\title{
Success Factors of Rural Entrepreneurs in Malaysia: The Proposed Model
}

\section{Rikinorhakis Ridzwan, Mohammad Ikram Ramzi, Ahmad Mudzfir Zubir}

To Link this Article: http://dx.doi.org/10.6007/IJARBSS/v11-i4/9678

Received: 11 February 2021, Revised: 12 March 2021, Accepted: 28 March 2021

Published Online: 17 April 2021

In-Text Citation: (Ridzwan et al., 2021)

To Cite this Article: Ridzwan, R., Ramzi, M. I., \& Zubir, A. M. (2021). Success Factors of Rural Entrepreneurs in Malaysia: The Proposed Model. International Journal of Academic Research in Business and Social Sciences, 11(4), 315-323.

\section{Copyright: (c) 2021 The Author(s)}

Published by Human Resource Management Academic Research Society (www.hrmars.com) This article is published under the Creative Commons Attribution (CC BY 4.0) license. Anyone may reproduce, distribute, translate and create derivative works of this article (for both commercial and non-commercial purposes), subject to full attribution to the original publication and authors. The full terms of this license may be seen at: http://creativecommons.org/licences/by/4.0/legalcode

Vol. 11, No. 4, 2021, Pg. 315 - 323

Full Terms \& Conditions of access and use can be found at http://hrmars.com/index.php/pages/detail/publication-ethics 


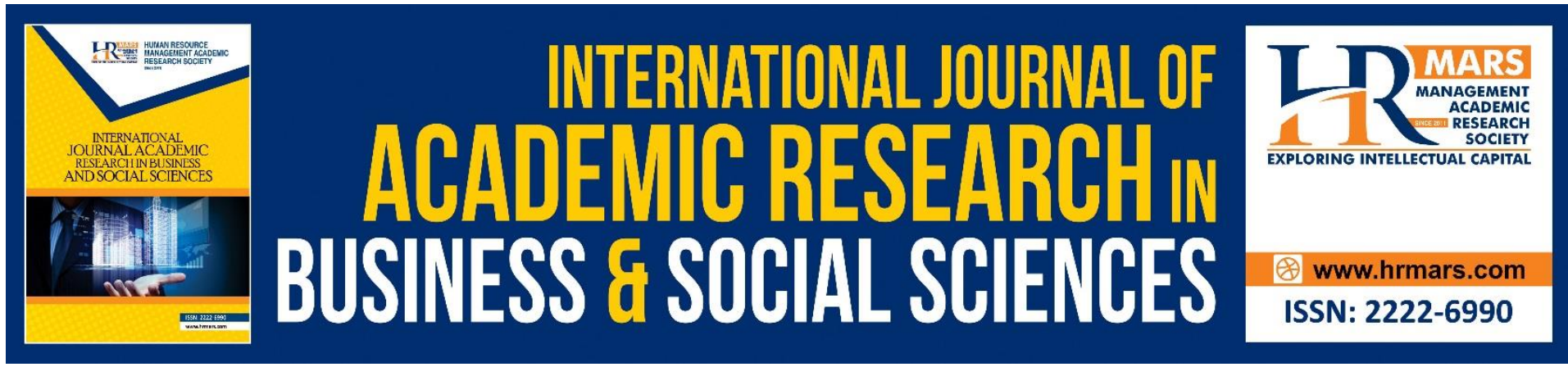

\title{
Success Factors of Rural Entrepreneurs in Malaysia: The Proposed Model
}

\author{
Rikinorhakis Ridzwan, Mohammad Ikram Ramzi, Ahmad \\ Mudzfir Zubir \\ Faculty of Business and Management, Universiti Teknologi Mara, Kelantan, Malaysia
}

\begin{abstract}
Entrepreneurial activities, especially among rural entrepreneurs has become one of the contributing factors to economic development. Various studies and literature had discussed the factors influencing toward entrepreneurship success which will affect the growth and sustainability of business performance. As the Malaysian economy is affected by covid-19, people can no longer rely on job opportunities. Engaging in entrepreneurial activities is the best way to help improve the economy whether for individuals, families, local communities, or even the country. From that, this study aims to propose a model based on the combination of entrepreneur's characteristics, managerial skills, and external environment factors toward entrepreneurship success in social entrepreneurship among rural entrepreneurs. The outcome of this research will contribute to the development of rural entrepreneurs as well as help them to improve their business performance. Hence, the government transformation program related to entrepreneurship also can be achieved successfully through fulfilling the national key results areas that relate to entrepreneurship nation.

Keywords: Entrepreneurship, Rural Entrepreneurs, Enterprise Success, Personality Trait, Managerial Skills, Environmental Factors.
\end{abstract}

\section{Introduction}

Entrepreneurship stand out as an important aspect for a number of reasons, from promoting social change to encouraging innovation. Entrepreneurs often regarded as national assets to be nurtured, motivated, and remunerated to the greatest possible extent. Nowadays, entrepreneurial activities has become one of the contributing factors towards economic development. Until now, research into micro and small sized enterprises (MSEs) especially among rural entrepreneurs has grown during the last decade. A huge majority of firms worldwide are MSEs, and they play a significant role in the economy (Islam, Khan, Obaidullah, \& Alam, 2011; Zin \& Ibrahim, 2020). Consequently, the performance of the MSE sector is closely associated with the performance of the nation. At the same time, the concept of entrepreneurship success has been widely studied at a global level (Katongole, Ahebwa, \& Kawere, 2014). There are numerous literature had discussed the factors influencing toward enterprise success which will affect the growth and sustainability of business performance. Analyzing literature on success factors first of all requires defining the notion of 
entrepreneurship success. There is no single agreed-upon definition of enterprise success, but researchers generally use continued viability or longevity as a surrogate for enterprise success. From that, Stefanovic, Prokic, \& Rankovic (2010) summarized that the critical factors influences the success of MSEs, which are (1) the psychological and personality traits of entrepreneurs, (2) the managerial skills and training of entrepreneurs and (3) the external environment. Besides those factors, the competencies among rural entrepreneurs will also cause positive affect toward management of business. Sánchez (2012) reported that entrepreneur's competencies plays an influential role in enterprise and has a direct effect on business performance. Ahmad, Ramayah, Wilson and Kummerow (2010) reported that competencies are strong predictors of business success in SMEs, and the association between competencies and business success was more strongly evident in hostile and dynamic environments than in more stable environments. While previous study by Brophy and Kiely (2002) found that the term of competencies especially on entrepreneur's managerial skills are leading to a studied approach to identify behaviors that may be associated with the success of a business.

Entrepreneurship is not a foreign field for today's society where it will become increasingly relevant in the future. As the Malaysian economy is affected by covid-19, people can no longer rely on job opportunities. Engaging in entrepreneurial activities is the best way to help improve the economy whether for individuals, families, local communities, or even the country (Ridzwan, Muhammad \& Rahman, 2016). The research focused on entrepreneurship increasingly for the past few years owing chiefly to the findings and realization by economic analysts throughout the world that small firms contribute substantially to the greater economic development and vitality of any society or country at large (Zin \& Ibrahim, 2020). There have been long attempted by Malaysian's government to increase the number of successful entrepreneurs across the country and provide them with all the necessary support such as improve new and old products, improved technologies and existence of government-authorized agents such as such as MARA, MARDI, FRIM and etc. (Paul, Hamazah, Samah, Ismail, \& D'Silva, 2014; Ridzwan, Muhammad \& Rahman, 2017). The Malaysian government has also allocated funds in encouraging entrepreneurship for growth where a total of RM500mil from these schemes will be designated for Bumiputera entrepreneurs to increase their involvement in the key sectors (The Star, 2020).

In recent years, there are increasing number of entrepreneurs from rural areas who are entered in the field of entrepreneurship. The world has seen the continued growth of micro and small enterprises (MSEs) as the backbone of the country and is the largest employer in the country, where it is important to not only help small businesses weather the Covid-19 storm, but also to nurture more entrepreneurs to drive the economy. Today, around the world, there are many rural entrepreneurs have become millionaires. In this regard, it is the best idea to identify what are the characteristics they have that make them success in their business endeavor. Therefore, the aim of this study is to propose a model based on the combination of personality traits, managerial skills, and external environment factors toward enterprise success especially on rural entrepreneurs.

\section{Literature Review}

\section{Micro and Small sized Enterprises (MSEs) Success}

According to Fisher, Maritz, and Lobo (2014), successful entrepreneurs is a phenomenon that seems to be understood by implication or context. There are more often referred to in a grammatical construct when talking about success in the context of enterprise. Crane and 
Crane (2007) in previous studied had summarized three important indicators for enterprise success which are entrepreneur achievement, the enterprise growth, and the business venture's success. Recently, the attainment of wealth or benefits had been noticed as a typical indicator of success (McMullen, \& Shepherd, 2006). Yet, other research shows many entrepreneurs do not necessarily consider creation of wealth as a measure of their success (Alstete, 2008; Evans et al., 2017). Furthermore, Storey (2011) also suggested that it is good to use measurement of business success based on achievement or failure in the area of management, but sometimes it can occur for other reasons such as luck. In term of success, it can be refer to business survival or growth. While, for failure, it sometimes can be refer to bankrupt or existing from business world (Gorgievski, Ascalon, \& Stephan, 2011).

The secret of success has long fascinated people, but most of the studies have focused on large companies. There are still needed for the study based on micro and small sized enterprise (MSEs) success especially in Malaysia context. Some of the studies have compared the measurement of success based on economic and non-economic indicators. The noneconomic aspects of success are particularly important in the context of MSEs because these firms often lack historical information and do not follow accurate accounting records that are comparable across firms (Hughes, Jennings, Brush, Carter \& Welter, 2012). While, measurement of entrepreneurship success based on economic perspective is difficult, especially in MSEs. It is because; some of the scholars have started to cast doubt regarding the appropriateness of economic indicators of enterprise success to MSEs (Katongole et al., 2014). Because of that, it is good for the current study to use non-economic indicators for measurement of entrepreneurship success because the micro and small sized enterprise or rural entrepreneurs are often lacking historical information about their business activities.

\section{Related theories of Entrepreneurship Success}

Entrepreneurship success is related to growth of the business or venture creation. According to Van Gelderen, Thurik and Bosma (2005), growth of venture creation approaches are come from the idea of Gartner's (1985) based the characteristics of entrepreneur in achieving their business success. Many theories of success had been proposed by different scholars that are related on development of enterprise and success. According to Simpeh (2011), the theory of enterprise success are ranging from economics to psychology, from sociological to anthropological, and also including from opportunity-based to resource-based. The development of those theories recently has given great attention among many scholars of entrepreneurship areas (Perez \& Canino, 2009; Simpeh, 2011). From economic entrepreneurship theory perspectives, it is suggested by Schumpeter and Backhaus, 2003) that economic conditions can be one of the influencing factors toward the development of entrepreneurial behavior. For psychological theory, characteristics of entrepreneurs can determine the success of their business (Gartner 1985). While from sociological area, the value of social context can be the main factors in affecting the growth of the certain enterprise (Reynolds, 1992).

Other entrepreneurship theories are anthropological, opportunity and resourcebased theory. Based on anthropological theory, it is argued by Hofstede (1991) that culture affects will influence the success of entrepreneurs. By Drucker (1985) perspectives, opportunity-based theory is also appropriate theory which is related to success. This types of theory limited to the opportunities that change in technology, customer preference, and so on. The last theory suggested by Simpeh (2011) is resource-based theory. This theory is most popular theory among those six theories. It is because, this theory exploit the benefits of 
resources for enterprise development. Those resources can be tangible (e.g. human resource, financial, etc.) or intangible (e.g.: training, reputation, goodwill, etc.) resources (Barney, 1991). As summarized, those theories are the appropriate theories in explaining the enterprise growth. It can be used in determining the factors for enterprise success for this current study.

\section{Factors Influencing of Enterprise Success}

One of the key questions that researchers have attempted to answer is the factors influencing success of enterprises. They have shown that the market structure has a significant influence on enterprise success. Some scholars in economics area found that the major determinants of enterprise success may include the characteristics of the industry in which the firm operates (Badini, Hajjar \& Kozak, 2018; Katongole et al., 2014). It is also argued that certain enterprise's has positive affects to its competition and the quality as well as quantity of the enterprise's resources. There are certain factors that lead to achievement and success of enterprise. According to Hassan, et al. (2014), the factors of internal and external environment such as financial efficiency, management, location, investment in technology, production costs and network had been discussed based on previous studied. While, the researchers like Azmi, Nik Hairi and Lee (2012); Benzing, Chu and Kara (2009); and Groenewegen and de Langen (2012) argued that the success of a business or enterprise is also depending on the owners including honesty, friendliness, creativity, courage, humility, willingness to learn, strategic thinking, strong determination and openness to new information. This elements are more to the internal environment which is refers to the entrepreneurial attributes.

According to Frese and Gielnik (2014), the psychological or entrepreneur's characteristics such as a drive for independence, innovative orientation, attitude toward risk and a competitive nature are been found to relate to success. These factors are especially important when an entrepreneur is working in a difficult business environment. Managerial factors are also an accepted element for enterprise success (Fisher et al., 2014). Managerial skills would include the ability of entrepreneur's in managing personnel and maintaining the accounting records to make sure that all the business activities going well (Stefanovic et al., 2010). From that, Fisher, Graham and Compeau (2008) suggested that elements of knowledge and skill can be used as measurement for managerial factors. Lastly is environmental factor. This type of factor would be related to satisfactory government support, access to capital and support of family and friends (Benzing et al., 2009). Studied by Hassan, et al. (2014) also supported that the factors of external or environment, such as government supports, availability of financial resources and supports from others (family, friend, etc.) (Zin \& Ibrahim, 2020) may influence for the success of rural entrepreneurs in Malaysia. The combination of those factors will contribute to enterprise success especially on rural entrepreneurs in Malaysia.

\section{Development of Proposed Framework}

The focus of this study will examine the relationship between influencing factors (entrepreneur's characteristics, managerial skills, and environment factors) with enterprise success among rural entrepreneurs. From the reviewed literature and the theories that support the argument, Figure 1 shows the proposed model for this current study: 


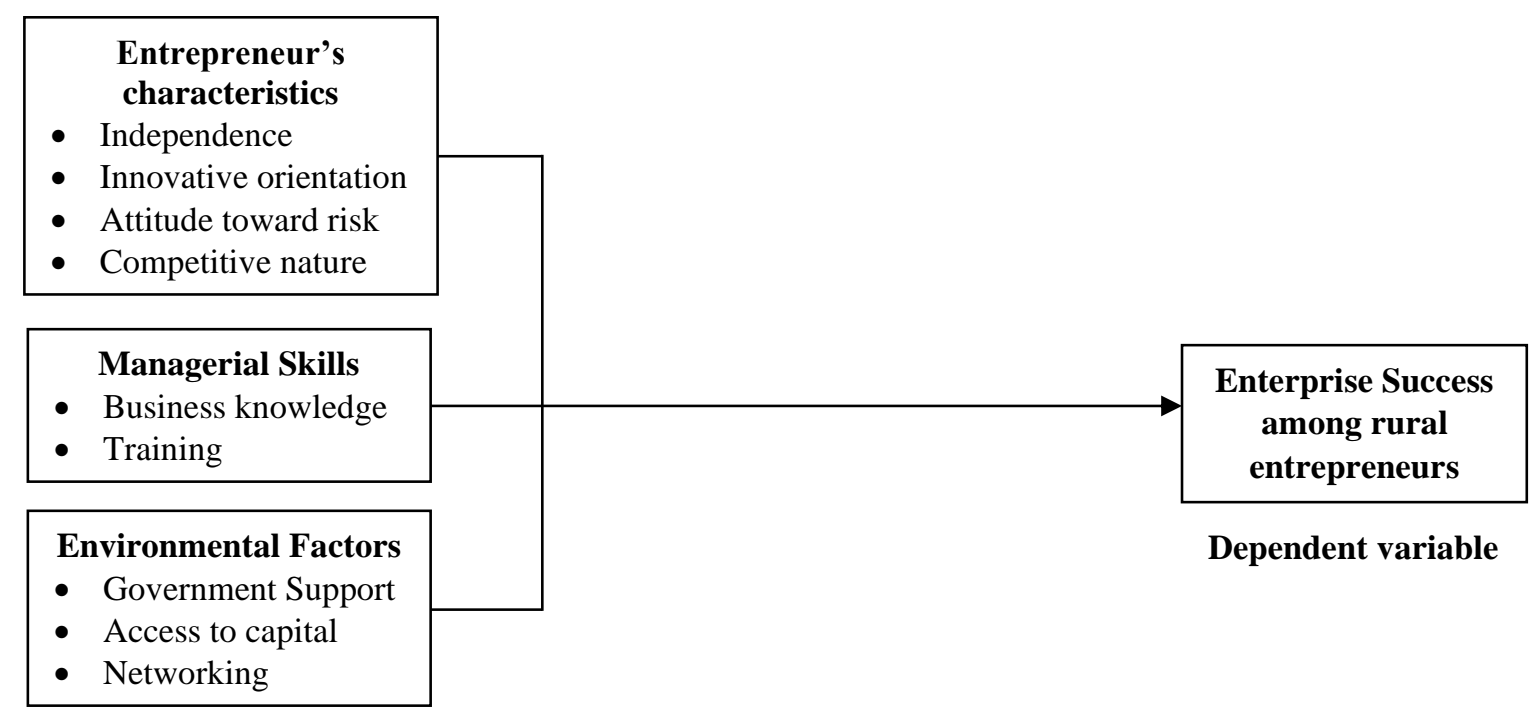

Independent variable

Figure 1: Proposed Model

(Sources: Hassan, et al., 2014; Stefanovic et al., 2010)

\section{Findings, Discussion and Conclusions}

From the previous arguments, it is show that the important role of entrepreneurship study in guiding entrepreneurs especially in rural area in improving their business performance (Stefanovic et al., 2010). It is proved that the entrepreneurial activities can be benefits to many parties such as practitioners, management and also government sector. In line with the previous studies, this study will use the factors such as entrepreneur's characteristics (independence, innovative orientation, attitude toward risk, competitive nature), managerial skills (business knowledge, training) and environmental factors (government support, access to capital, networking) towards enterprise success among rural entrepreneurs especially in Malaysia. These factors are expected to positively affect the enterprise success of rural entrepreneurs which will also be a guide for the success factors of other entrepreneurs such as youth entrepreneurs, women, and others. This is because nowadays, entrepreneurial activities have grown importance through the past decades at the macroeconomic level, making it a powerful engine for economic development; and at the micro-level as a factor for business renewal and innovation of new products and processes. Studying entrepreneurship in depth in general and entrepreneurship in MSEs sectors in Malaysia in specific will help in comprehension pioneers and additionally revealing insight into the challenges business enterprise ventures confront (Najim, El-Refae \& Alnaji, 2013). Moreover, the present study is significant in contributing to the new body of knowledge and useful in many ways. The outcome of this research will contribute to the development of rural entrepreneurs as well as help them to improve their business performance. At the same time, it is also will help the government's realization on entrepreneurial nation and also help the practitioner understand the role of rural entrepreneurs, contributing to economic development. Hence, the government transformation program related to entrepreneurship also can be achieved successfully through fulfilling the national key results areas that relates to entrepreneurship nation.

The aim of this study is to determine the entrepreneur's characteristics, managerial skills, and environment factors that influence the success of rural entrepreneur in micro and 
small sized business. It is been argued by previous studied that, in order to succeed in the business endeavor, the rural entrepreneurs need to have confidence and determination as well as vision, managerial skills and the effectiveness of networking. Based on previous findings, the researchers will propose that to increase the number of successful rural entrepreneurs in Malaysia, other entrepreneurs should emulate entrepreneurs who have been successful. Key entrepreneurial traits, managerial skills possessed by successful entrepreneurs and networking should be instilled in every other entrepreneur if they want to succeed in their business. The responsible parties for business people's advancement programs additionally prescribed to assume their parts as far as giving capital as well as give projects that can help business people increment their certainty, boldness and their openness to challenge in business.

\section{References}

Ahmad, N. H., Ramayah, T., Wilson, C., \& Kummerow, L. (2010). Is entrepreneurial competency and business success relationship contingent upon business environment?. International Journal of Entrepreneurial Behavior \& Research, 16(3), 182-203.

Alstete, J. W. (2008). Aspects of entrepreneurial success. Journal of small business and enterprise development, 15(3), 584-594.

Azmi, A. M., Nik Hairi, O., \& Lee, K. Y. (2012). Faktor kritikal kejayaan usahawan dalam perniagaan/Azmi Abdul Manaf, Nik Hairi Omar, Lee Kuan Yee. e-BANGI: Jurnal Sains Sosial dan Kemanusiaan, 7(1), 34-45.

Badini, O. S., Hajjar, R., \& Kozak, R. (2018). Critical success factors for small and medium forest enterprises: A review. Forest Policy and Economics, 94, 35-45.

Barney, J. (1991). Firm resources and sustained competitive advantage. Journal of management, 17(1), 99-120.

Benzing, C., Chu, H. M., \& Kara, O. (2009). Entrepreneurs in Turkey: A factor analysis of motivations, success factors, and problems. Journal of small business management, 47(1), 58-91.

Brophy, M., \& Kiely, T. (2002). Competencies: A new sector. Journal of European Industrial Training, 26(2/3/4), 165-176.

Crane, F. G., \& Crane, E. C. (2007). Dispositional optimism and entrepreneurial success. The Psychologist-Manager Journal, 10(1), 13-25.

Drucker, P. (1985). Innovation and Entrepreneurship, New York, Harper \& Row Published.

Evans, S., Vladimirova, D., Holgado, M., Van Fossen, K., Yang, M., Silva, E. A., \& Barlow, C. Y. (2017). Business model innovation for sustainability: Towards a unified perspective for creation of sustainable business models. Business Strategy and the Environment, 26(5), 597-608.

Fisher, R., Maritz, A., \& Lobo, A. (2014). Evaluating entrepreneurs' perception of success. International Journal of Entrepreneurial Behavior \& Research 20(5), 478-492.

Fisher, S. L., Graham, M. E., \& Compeau, M. (2008). Starting from scratch: Understanding the learning outcomes of undergraduate entrepreneurship education. In Entrepreneurial learning: Conceptual frameworks and applications (pp. 313-337). Routledge Taylor \& Francis Group.

Frese, M., \& Gielnik, M. M. (2014). The psychology of entrepreneurship. Annual Review of Organizational Psychology and Organizational Behavior, 1(1), 413-438. 
Gartner, W. B. (1985). A conceptual framework for describing the phenomenon of new venture creation. Academy of management review, 10(4), 696-706.

Gorgievski, M. J., Ascalon, M. E., \& Stephan, U. (2011). Small business owners' success criteria, a values approach to personal differences. Journal of Small Business Management, 49(2), 207-232.

Groenewegen, G., \& de Langen, F. (2012). Critical success factors of the survival of start-ups with a radical innovation. Journal of Applied Economics and Business Research, 2(3), 155-171.

Hassan, F., Ramli, A., \& Desa, N. M. (2014). Rural women entrepreneurs in Malaysia: What drives their success?. International Journal of Business and Management, 9(4), 10.

Hofstede, G. (1991). Management in a multicultural society. Malaysian Management Review, 26(1), 3-12.

Hughes, K. D., Jennings, J. E., Brush, C., Carter, S., \& Welter, F. (2012). Extending women's entrepreneurship research in new directions. Entrepreneurship theory and practice, 36(3), 429-442.

Islam, M. A., Khan, M. A., Obaidullah, A. Z. M., \& Alam, M. S. (2011). Effect of entrepreneur and firm characteristics on the business success of small and medium enterprises (SMEs) in Bangladesh. International Journal of Business and Management, 6(3), 289299.

Katongole, C., Ahebwa, W. M., \& Kawere, R. (2014). Enterprise success and entrepreneur's personality traits: An analysis of micro-and small-scale women-owned enterprises in Uganda's tourism industry. Tourism and Hospitality Research, 13(3), 166-177.

McMullen, J. S., \& Shepherd, D. A. (2006). Entrepreneurial action and the role of uncertainty in the theory of the entrepreneur. Academy of Management review, 31(1), 132-152.

Najim, N. A., El-Refae, G. A., \& Alnaji, L. (2013). The impact of the key dimensions of entrepreneurship on opportunities for the success of new ventures in the greater amman municipality. European Journal of Business and Management, 5(4), 159-173.

Paul, K. C., Hamazah, A., Samah, B. A., Ismail, I. A., \& D'Silva, J. L. (2014). Rural Malay involvement in Malaysian herbal entrepreneurship. Asian Social Science, 10(2), 202208.

Perez, E. H., \& Canino, R. M. B. (2009). The importance of the entrepreneur's perception of "success". Review of International Comparative Management, 10(5), 990-1010.

Reynolds, P. D. (1992). Sociology and entrepreneurship: Concepts and contributions. Entrepreneurship theory and practice, 16(2), 47-70.

Ridzwan, R., Muhammad, N. M. N., \& Rahman, A. A. A. (2016). Resources, social network competence and youth entrepreneur success: A proposed framework. International Journal of Academic Research in Business and Social Sciences, 6(12), 469-480.

Ridzwan, R., Muhammad, N. M. N., \& Rahman, A. A. A. (2017). Issues and challenges among young entrepreneurs in Malaysia. IOSR Journal of Business and Management, 19(03), 80-84.

Sánchez, J. (2012). The influence of entrepreneurial competencies on small firm performance. Revista Latinoamericana de Psicologia, 44(2), 165-177.

Schumpeter, J., \& Backhaus, U. (2003). The theory of economic development. In Joseph Alois Schumpeter (pp. 61-116). Springer, Boston, MA.

Simpeh, K. N. (2011). Entrepreneurship theories and Empirical research: A Summary Review of the Literature. European Journal of Business and Management, 3(6), 1-8.' 
Stefanovic, I., Prokic, S., \& Rankovic, L. (2010). Motivational and success factors of entrepreneurs: the evidence from a developing country. Zbornik radova Ekonomskog fakulteta u Rijeci: časopis za ekonomsku teoriju i praksu, 28(2), 251-269.

Storey, D. J. (2011). Optimism and chance: The elephants in the entrepreneurship room. International Small Business Journal, 29(4), 303-321.

The Star (2020). Encouraging entrepreneurship for growth. Retrieved at: https://www.thestar.com.my/news/nation/2020/12/17/encouragingentrepreneurship

Van Gelderen, M., Thurik, R., \& Bosma, N. (2005). Success and risk factors in the pre-startup phase. Small business economics, 24(4), 365-380.

Zin, M. L. M., \& Ibrahim, H. (2020). The influence of entrepreneurial supports on business performance among rural entrepreneurs. Annals of Contemporary Developments in Management \& HR (ACDMHR), 2(1), 31-41. 